\title{
КРИТИКА nements
}

\section{Черное солнце и огороженный простор: образы неволи в творчестве Сергея Параджанова и Кадзуки Ясуо}

\author{
Э.-Б. М. Гучинова \\ КАЛМЫЦКИЙ НАУЧНЫЙ ЦЕНТР РАН
}

Аннотащия. Статья посвящена творчеству двух выдающих художников - Сергея Параджанова (СССР) и Кадзуки Ясуо (Япония). Параджанов был осужден и провел пять лет в лагерях, Кадзуки оказался в советском лагере для военнопленных. Унизительный опыт заключения художников отразился в их творчестве, которое не прекращалось и за колючей проволокой. Параджанов свое лагерное творчество так и обозначил - огороженный простор. Он и Кадзуки использовали техники бриколажа, причем японский художник сам компоновал состав красок, поскольку фабричные цвета не передают чужое черное солнце. В то же время нахождение в принципиально иных лагерях отразилось в портретах заключенных: колоритных лицах у Параджанова и деперсонализованных фигурах Кадзуки. Параджанов и Кадзуки создают куклы, коллажи, автопортреты и лого, частью которого становится лагерная проволока, или лого, в котором автопортрет является рабочим инструментом пленника.

Ключевые слова: язык травмы, травматическое прошлое, лагерь, Гулаг, память.

УДК 929: 75(47 + 57)Параджанов + 159.9

DOI 10.25205/2307-1737-2019-2-78-99

Контактная информация: Гучинова Эльза-Баир Мацаковна, доктор исторических наук, ведущий научный сотрудник, Калмыцкий научный центр РАН (ул. Илишкина, 8, Элиста, 358000, Россия, kigiran@mail.ru)

* Статья опубликована в кн.: Imagining the Landscape: Views from Armenia and Japan / Ed. by Tadashi Nakamura (Comparative Studies on Regional Powers, no. 12). Sapporo, Slavic Research Center, Hokkaido University, 2013, p. 47-61.

Гучинова Э.-Б. М. Черное солнце и огороженный простор: образы неволи в творчестве Сергея Параджанова и Кадзуки Ясуо // Критика и семиотика. 2019. № 2. С. 78-99.

ISSN 2307-1737. Критика и семиотика. 2019. № 2

(C) Э.-Б. М. Гучинова, 2019 
Творчество двух великих художников Сергея Параджанова и Кадзуки Ясуо пришлось на вторую половину XX в. Несмотря на многие исторические и политические обстоятельства, которые отличали жизнь и творчество художников, в творчестве Параджанова и Кадзуки можно увидеть общие черты. Параджанов и Кадзуки жили в разных социальных контекстах, творили в разных жанрах. Но каждый имел опыт заключения, который так или иначе повлиял на художников и на их творчество.

Ясуо Кадзуки (1911-1974) родился в г. Мисуми в префектуре Ямагучи. Рано осиротев, он стал рисовать в возрасте 16 лет и получил художественное образование вначале в художественной школе Кавабаты, затем в школе искусств в Токио. Кадзуки Ясуо был призван в ряды Квантунской армии и служил в ней, пока ее солдаты и офицеры не были вынуждены подчиниться рескрипту императора о капитуляции от 15 августа 1945 г. Квантунская армия перешла в Маньчжурии в распоряжение Красной Армии. 640 тысяч солдат и офицеров Квантунской армии были вывезены в СССР и прошли через лагеря ГУПВИ, где десятая их часть сгинула от истощения и непосильного труда [Катасонова, 2003; Кузнецов, 1997]. Кадзуки провел на фронте и в плену 4,5 года. После возвращения из Сибири в 1947 г. он продолжил писать и быстро получил национальное признание. Картины Кадзуки хранятся в крупных музеях современного искусства Японии, а в его родном городе открыт музей творчества Ясуо Кадзуки.

Сергей Параджанов (1924-1990) родился в Тбилиси. В 1952 г. он закончил Институт кинематографии (ВГИК). После фильма «Тени забытых предков» (1964) получил всемирное признание. Великий режиссер свободно выражал свои мысли и в кругу друзей и в публичных выступлениях, где имел смелость не соглашаться с линией руководящей партии, что не могло остаться безнаказанным. По сфабрикованному обвинению, а фальсификация и тайна становятся базовыми стратегиями тоталитарной власти в борьбе с инакомыслящими, С. Параджанов дважды был арестован. После первого суда в 1974 г. он получил приговор пять лет лагерей, из которых отсидел четыре года, отбывая наказание на Украине в лагерях усиленного режима. Во время второго ареста Параджанов 9 месяцев - с 11 февраля по 5 октября 1982 г. - отсидел в камере смертников Ортачальской тюрьмы в Тбилиси. Позже он назвал годы заключения и 15 лет молчания вокруг его имени - с 1970 (премьера «Цвета граната») и до 1985 (первый показ на Московском фестивале «Легенды о Сурамской крепости», снятой на киностудии «Грузияфильм») - «тремя пятилетками Гулага». Как отмечал армянский киновед Г. Закоян, Параджанов «родился, жил и творил в огромном лагере - СССР. Но творить означает волить свободу» [Сергей Параджанов..., 2000, с. 8].

Как же художник выражает свой травматический опыт? В свое время Варлам Шаламов сформулировал такой подход: «...предложить собственную кровь для жизни возникающего пейзажа», иначе говоря, собственную жизнь, себя, чтобы иметь право писать. Именно художник, чей талант позволяет ему видеть дальше и глубже, чем остальные, становится образцом подлинности, с которым пропитанное фальшью тоталитарное общество могло бы постоянно сверяться. Шаламов считал, что рассказывать о лагере надо так, чтобы показать «летопись души» [Шаламов, 2016, с. 135], - обратившись к воображению, насыщающему документ значением, соизмеримым с душой [Нич, 2011, с. 194].

O том, как были важны образы лагеря в литературе, красноречиво говорит человеческий и творческий подвиг Шаламова. Теперь уже можно сказать, что 
реальная Колыма со своим концентрационным адом существует лишь в той мере, в какой существуют «Колымские рассказы». В той же мере не существуют Воркута и Норильск, хотя творившееся там не менее апокалиптично [Нич, 2011, c. 154], потому что не нашлось художника, сумевшего рассказать об этом адекватно масштабам того ада.

Несколько десятков японских профессиональных и самодеятельных художников оставили нам образы советского лагеря. Маслом и графикой они передавали свое травматическое прошлое, и в этом ряду работы Кадзуки занимают особое место желанием подняться над бытовыми сюжетами и попыткой осмыслить лагерный опыт.

Цель настоящей статьи - проследить некоторые параллели в том, как лагерное прошлое отражается в творчестве Сергея Параджанова и Ясуо Кадзуки, в каких образах проявляется и как меняется саморепрезентация художника.

Для работ Кадзуки характерно обращение к экзистенциальным темам, Параджанову особенно удавались мифологические сюжеты. Но обоих художников объединяет тема свободы человека в несвободных условиях, где границы свободы могут быть очерчены и границами тоталитарного государства, и военным порядком на фронте, и колючей проволокой лагерной ограды.

\section{Колючая проволока как символ несвободы}

На рисунке Параджанова «Грузин - охрана. Зима!» (рис. 1) мы видим высокую ограду из колючей проволоки, отделяющей лагерь от остального мира. Эта ограда так высока, что достигает пояса охранника, стоящего на вышке. Там, за оградой, высится двуглавая гора наподобие Арарата и библейская птица летит на обетованную землю. У ограды охранник, грузин. Южному человеку холодно на морозе, хотя он одет достаточно тепло - валенки, овчинный полушубок, меховая шапкаушанка, но вышка, на которой он должен отстоять свой караул, не позволяет ему согреться. Вспоминается давно замеченное сравнение, ставшее уже общим местом, что судьба тюремщика мало отличается от судьбы заключенного, он тоже всю жизнь проводит за решеткой, хотя и в смягченном режиме. Это также метафора СССР как двух лагерей, двух зон - малой зоны, собственно лагеря, и большой зоны, в которой жили советские люди, но также не имевшие многих гражданских свобод. Эту метафору подчеркивают провода, уходящие в небо Советского Союза. Как будто реализованный по всей стране план ГОЭЛРО переходит в другой грандиозный план - план архипелага Гулаг.

На рисунке «Банный день в зоне» (рис. 2) Сергей Параджанов показывает, как человек привыкает к несвободе и обживает ее, невольно пытаясь приспособиться к ее условиям. В лагерном пространстве колючая решетка при необходимости превращается в бельевую веревку. Художник подчеркивает беззащитность заключенного - вот он весь голый, неприкрытый, и даже интимная область открыта перед системой, сильной и имеющей в распоряжении такие колючие ограды, вышки и армию охранников. Обнаженность заключенного, не имеющего запасной одежды, - не только бытовая деталь, но и проявление языка травмы в визуальном нарративе о лагерных годах [Гучинова, 2016, с. 198] - обнаженность человека говорит о годах экзистенциального неуюта. 


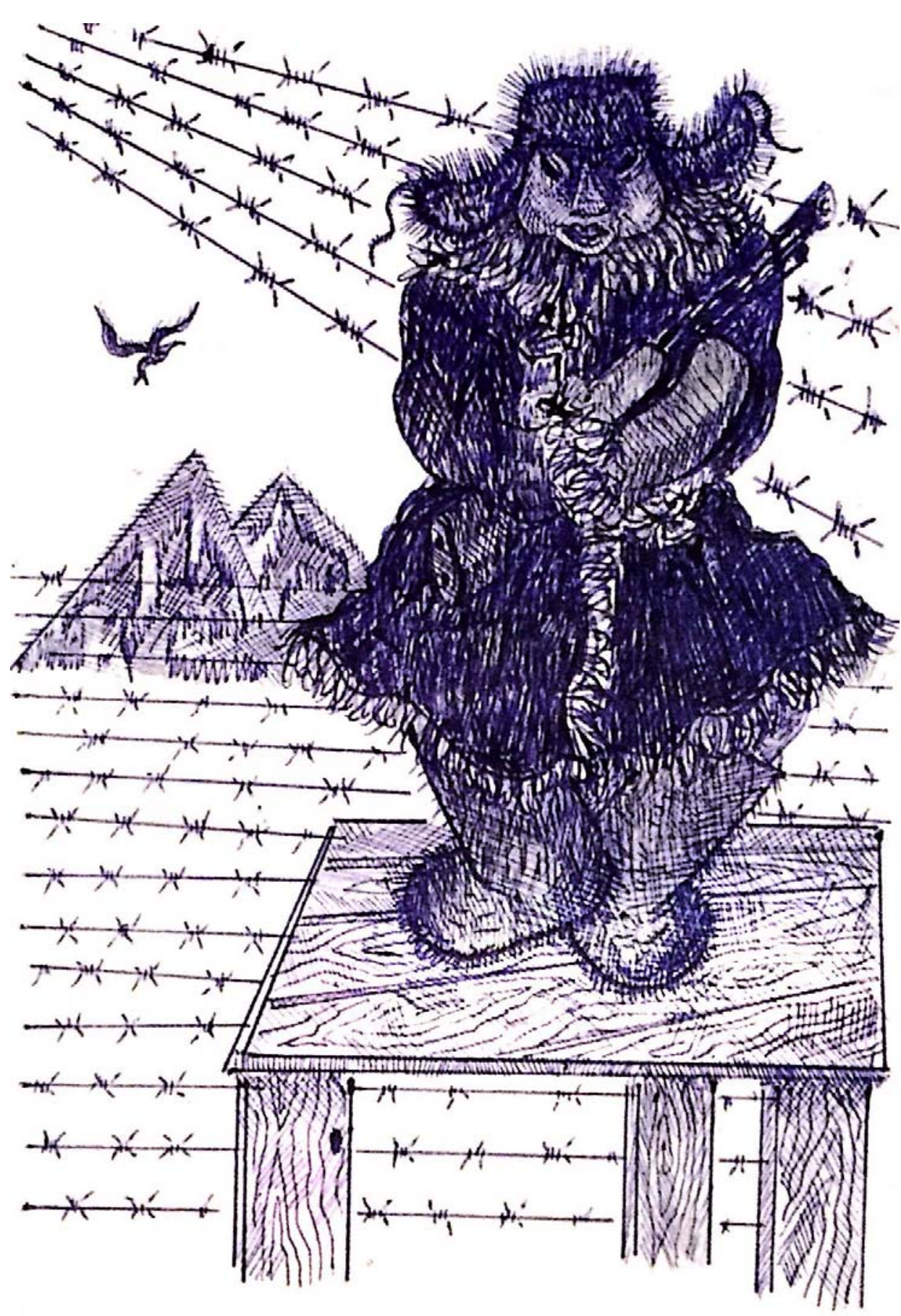

Puc. 1. Сергей Параджанов. Грузин - охрана. Зима! Рисунок на бумаге, 1974-1977 Fig. 1. Sergei Parajanov. Georgian Guard. Winter! Drawing on paper, 1974-1977 


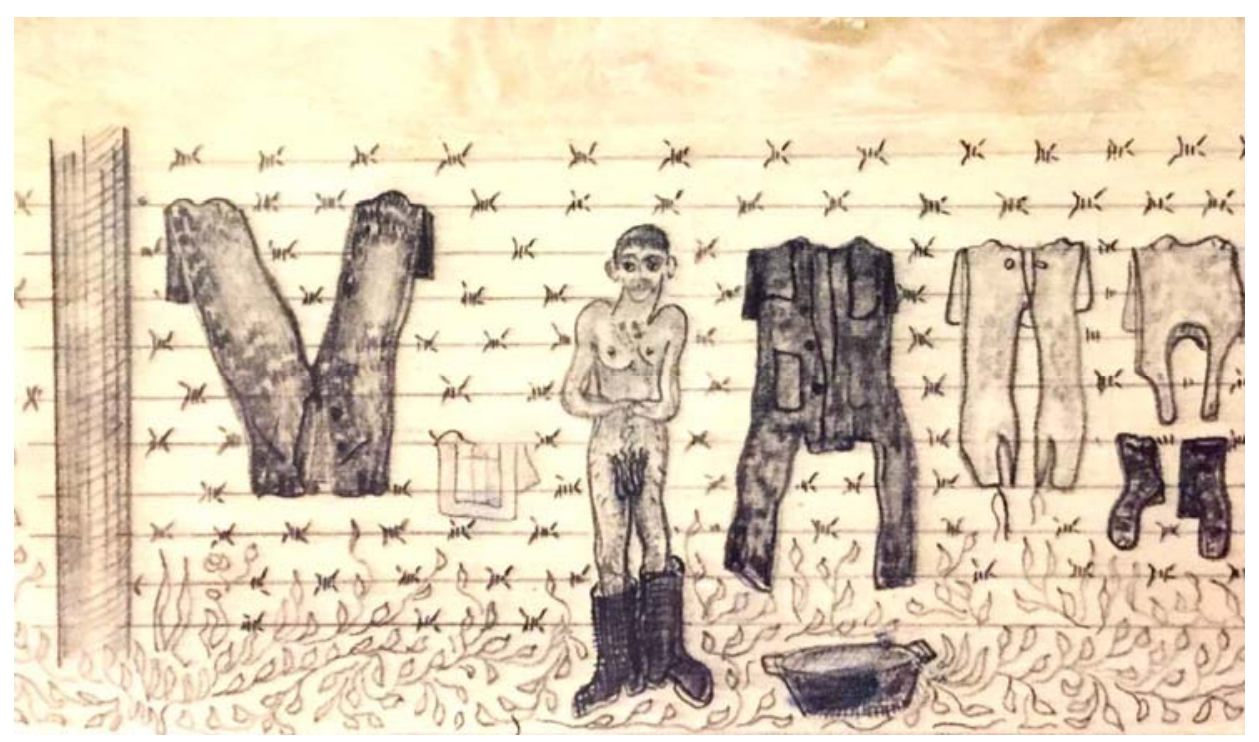

Puc. 2. Сергей Параджанов. Банный день в зоне. Рисунок на бумаге, 1974-1977 Fig. 2. Sergei Parajanov. Shower Day in Prison. Drawing on paper, 1974-1977

Колючая проволока настолько вошла в лагерные реалии, что оказалась частью декора на игральных картах, которые Параджанов рисовал для товарищей по заключению.

Колючая лагерная проволока проявилась и в работах Кадзуки Ясуо, более того, она стала частью миропорядка. Например, на картине «Колючая проволока, звезды, лето» (рис. 3) художник увидел рукотворные колючки - звездочки на проволоке, их строгий порядок напоминает строй солдат или строй заключенных. На земле мы видим только черную пустоту, здание барака в центре картины и колючую проволоку. Но и в кажущемся хаосе небесных звезд угадываются очертания пятиконечной звезды. Вот как он комментировал это изображение:

Сибирское лето красивое, хотя и короткое. Я не могу забыть быстротечную летнюю красоту сибирской природы. Это красота звезд. Выйдя из барака, полного вонючего пота, лежу на прохладной земле. Начинают мигать звезды одна за другой. Очень быстро. Во всем небе симпозиум звезд. Мы любовались красотой, которая нас связывала с Японией. Но не могли забыть реальность плена. Когда смотрю, очень четко вижу ограду. Когда я был в Сибири, я был отделен от звезд колючей проволокой [Kazuki, 1994, c. 84].

Прямым символом свободы для Параджанова и Кадзуки становятся птицы. Мы уже видели птицу, парящую над колючей проволокой и устремленную к Арарату. Кадзуки нарисовал сокола (рис. 4), хотя птица, навеявшая этот сюжет, была иной:

Однажды к нам прилетел, заблудившись, сапсан. Еще не взрослый, заболел и не мог лететь. Мы стали его кормить, дали ему еду и привязали веревку к его ноге. Но на другой день утром его не обнаружили, он улетел, великолепно порвав веревки. Я позавидовал тому, как птица своей силой смогла освободиться. Мне стало 
грустно, что у меня нет крыльев, чтобы улететь. Те веревки, что держат нас, не режутся так легко. Я изобразил сокола вместо сапсана, потому что хотел изобразить больше жизненной силы и способности к полету [Kazuki, 1994, с. 32].

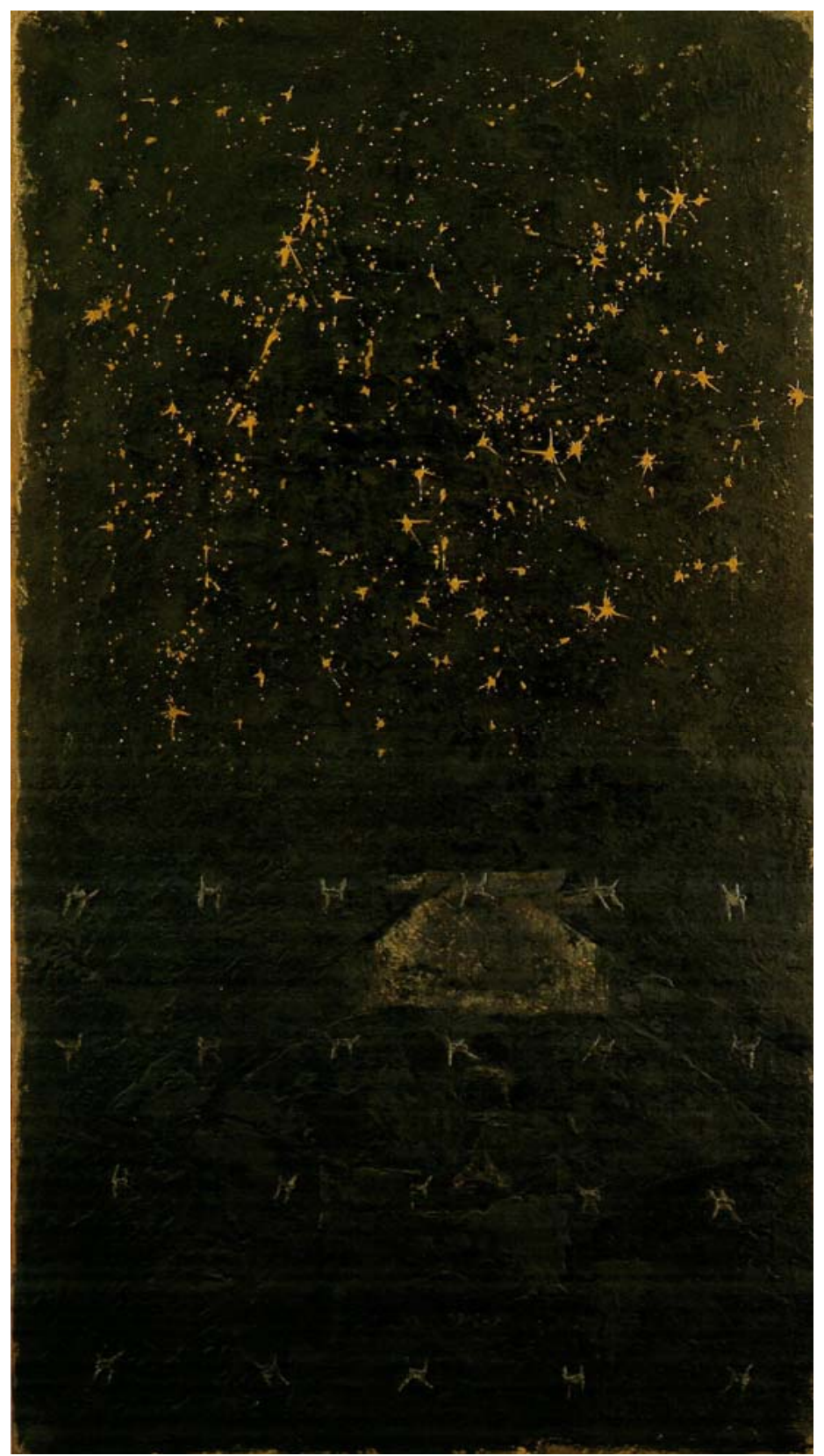

Puc. 3. Ясуо Кадзуки. Звезды (колючая проволока). Лето. Холст, масло, 1966 Fig. 3. Yasuo Kazuki. Stars (barbed wire). Summer. Cfnvas, oil, 1966 


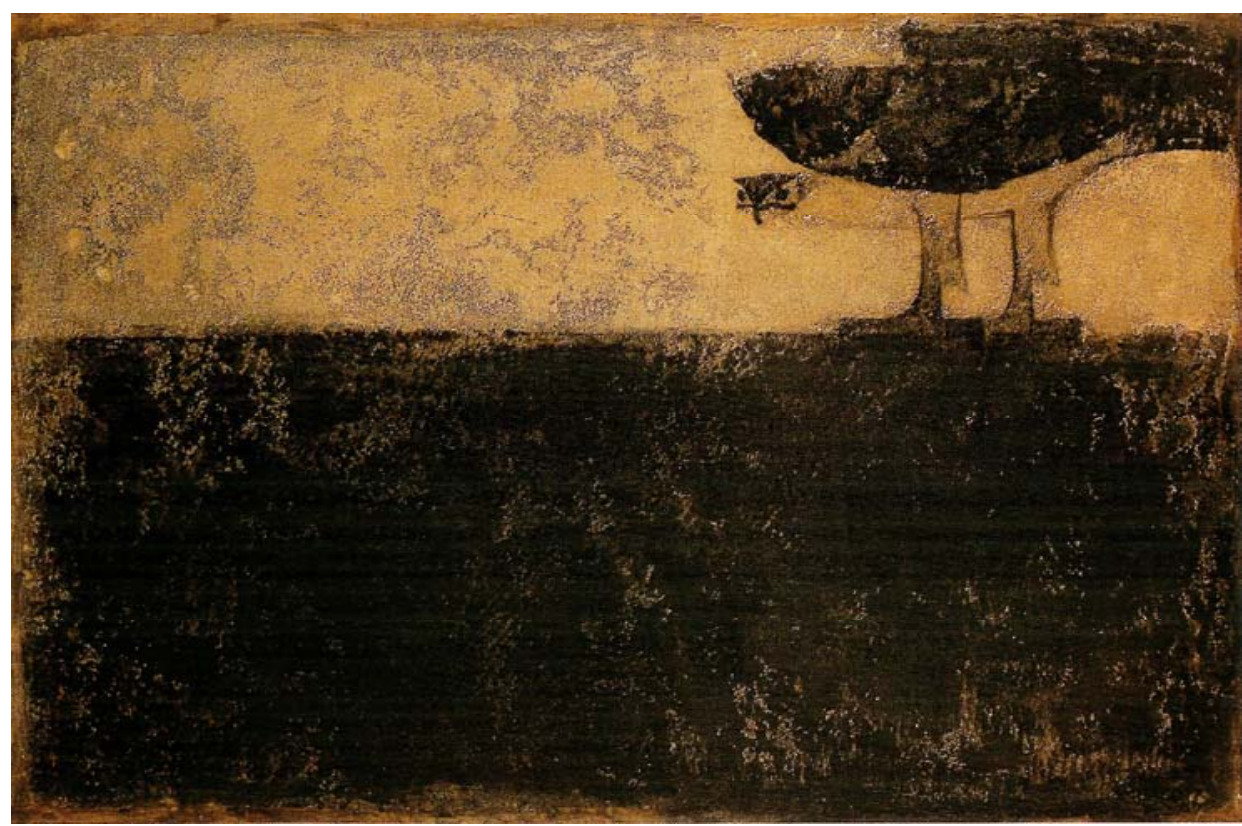

Puc. 4. Ясуо Кадзуки. Сокол. Холст, масло, 1958

Fig. 4. Yasuo Kazuki. Hawk. Canvas, oil, 1958

Ассоциируя птицу с пленником и заменяя сапсана соколом, Кадзуки хочет придать больше сил тому заключенному, оставшемуся в лагерном прошлом, себе и своим товарищам.

\section{Неволя и творчество}

Свое творчество в лагере Сергей Параджанов обозначил как огороженный простор. В этом оксюмороне проговаривается, что простор, даже творческий, можно огородить. Но несмотря на то, что для советского заключенного всегда находилась работа, Параджанов писал о том, какой насыщенной была его внутренняя жизнь:

Я был прачкой, дворником, штопальщиком мешков и даже пожарным. Однако не это главное. Главное, что я создал 800 рисунков и коллажей. Задумал удивительные литературные зарисовки, новеллы, либретто, сценарии (цит. по: [Орозбаев, 2011]).

Как видим, пространство свободы художника можно изолировать от круга родных и професионального сообщества, можно ограничить выбор материалов и виды техники. В заключении художник невольно переосмысливает не только свою судьбу, но и творческие задачи. Вынужденная ограниченность материалов расширяет спектр применения подручных средств, и уже можно вышивать надерганными из мешковины нитками, делать монеты и портреты из крышек из фольги от молочных бутылок, рисовать на носовых платках и исподних рубашках. 
Мы знаем, «из какого сора» росли произведения Параджанова в лагере и на свободе, но вот после лагеря Кадзуки возвращается домой и чувствует, что покупные краски его не удовлетворяют. Для изображения лагерного опыта ему нужны те краски, которые он добывал в лагере из сажи, почвы и растений. Так рождаются «Черное солнце» (рис. 5) и «Серое солнце».

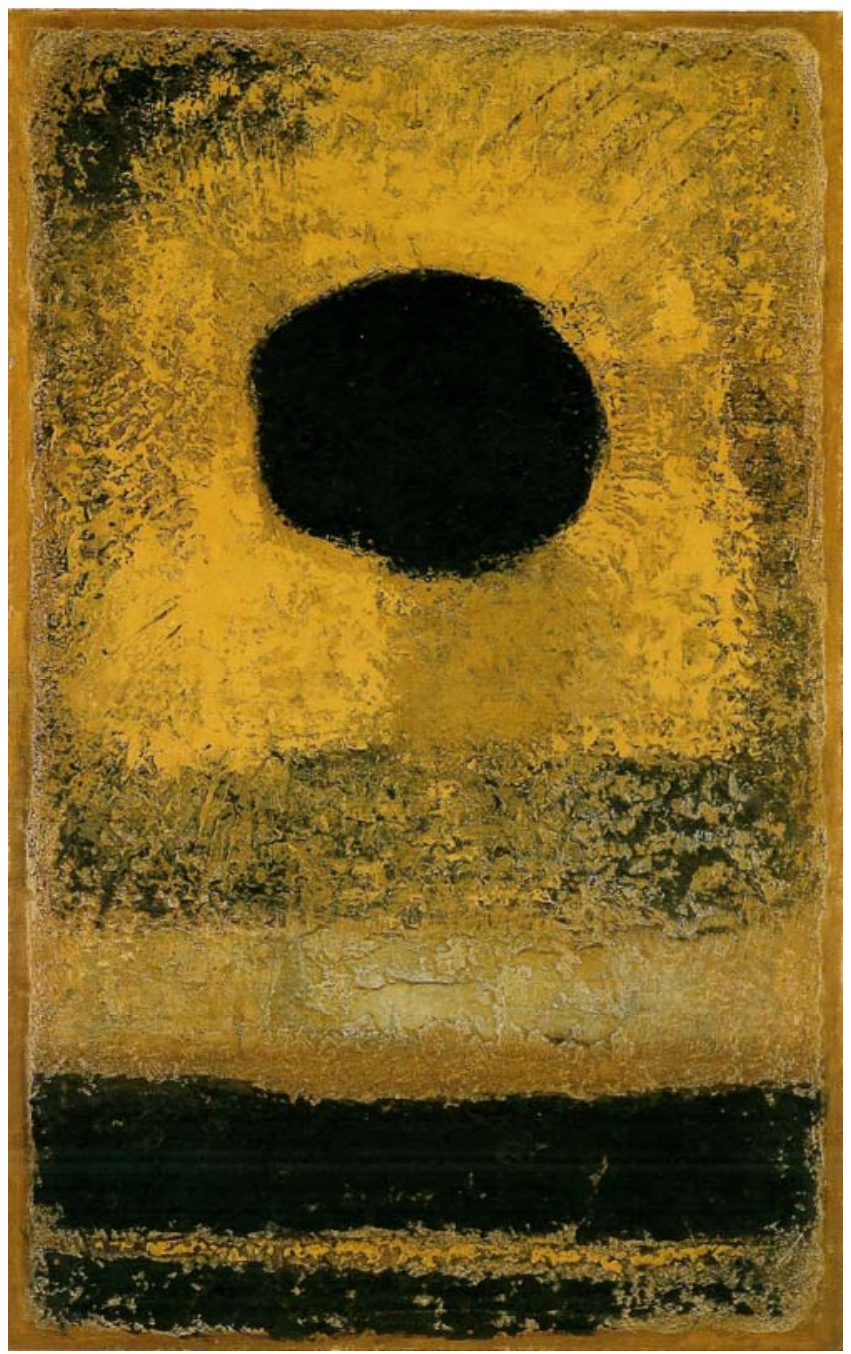

Puc. 5. Ясуо Кадзуки. Черное солнце. Холст, масло, 1961 Fig. 5. Yasuo Kazuki. Black sun. Painting in oil, 1961

Для пленных японцев лагеря Сибири прежде всего - это чуждая, климатически и географически недружественная среда: чужое небо, холод и снег. И даже солнце пленникам казалось другим. Вместо такого родного красного солнца хи-но мару Кадзуки рисует черное солнце. Позже он объяснит этот образ так: 
Даже это красивейшее солнце для меня, который связан клеткой, названной армией, перестало быть символом надежды. Солнце потеряло обычный блеск и показалось на небе черным шаром [Kazuki, 1994, с. 15].

Когда Кадзуки везли в Сибирь, он смотрел в окно вагона на улицу и думал:

...это можно нарисовать, это нельзя нарисовать, это не стоит рисовать. С такими мыслями мне было легче. Именно это спасало меня от чувства бессилия и усталости.

Я по-настоящему выучился рисовать в Сибири. До этого я думал, что художник рисует то, что предполагается нарисовать, и произведение рождается само по себе. Но в Сибири самая возможность рисовать была привилегией. Только тогда, когда я потерял эту привилегию, я узнал, что она необходима, как вода для рыбы, чтобы жить. Поэтому я хотел рисовать в Сибири независимо от оценок и репутации, просто рисовать. Раньше я с трудом искал предмет, а в Сибири все стихийно из меня вытекало, как родник [Kazuki, 1994, с. 158].

Кадзуки упоминает риск неодобрения товарищей и плохой репутации, на который он шел, чтобы стать лагерным оформителем наглядной агитации и иметь под рукой кисти и краски.

Хорошим подтверждением творческой плодотворности - того, как росли «цветы, не ведая стыда», стали тюремные букеты Сергея Параджанова (рис. 6). Это была классичекая техника бриколлажа - создание объектов искусства из подручных средств. Таким образом Параджанов создал сотни шедевров.

\section{Телесность и субъектность}

Как заметил А. Н. Мещеряков, в тоталитарную эпоху 40-х после призыва в армию тело японского солдата не принадлежало ему, оно было отчуждено в пользу родины и императора, а то, что принадлежало родине и императору, должно было содержаться в полном порядке [Мещеряков, 2012, с. 364]. Однако после рескрипта императора от 15 августа 1945 г. солдаты Квантунской армии на неопределенный срок перешли в распоряжение Красной Армии. В силу исторических обстоятельств за телами уже не было такого ответственного присмотра, и, утратив субъектность, возможность самому быть автором сценария собственной жизни, пленники стали постепенно чувствовать свои тела, которые к тому же стали быстро меняться - худеть и слабеть. Солдатские тела стали постепенно менять своего хозяина. Во время войны они принадлежали императору, затем находились в аренде у СССР и в лагере постепенно стали возвращаться к своему бывшему хозяину - личности человека. По мере того как военнопленный осознавал новую ситуацию и свои стратегии выживания, он начинал распоряжаться своим телом как своей собственностью.

Ясуо Кадзуки на своих полотнах изображал лица пленников и их руки (рис. 7), подчеркивая инструментальное значение пленения: советской власти прежде всего были нужны рабочие руки для восстановления народного хозяйства. Физические тела с их болезнями, голодом и холодом он только подразумевает, но бытовых лагерных сцен не изображает, как делает это большая часть японских художников-пленников. Он остается верен экзистенциальным проблемам, фокусируя их в лагерном локусе. Может быть, именно в таком контексте эта проблематика становится более обнаженной, как и сам человек, лишенный всего. 


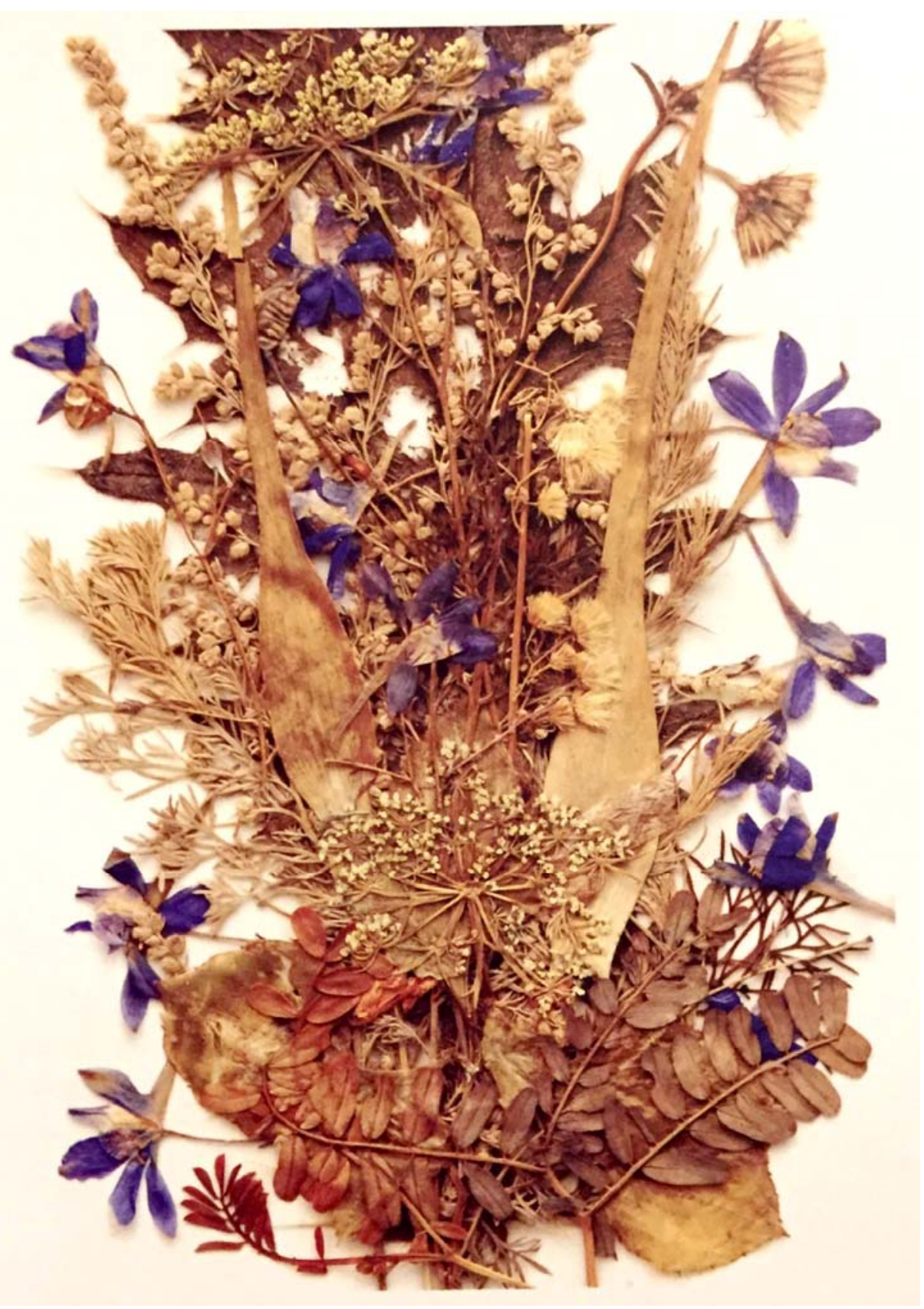

Puc. 6. Сергей Параджанов. Букет. Из серии «Притча о сыне». Засушенные цветы. 1977

Fig. 6. Sergei Parajanov. Bouquet. From the series «Parable about the Son». Dry flowers. 1977 


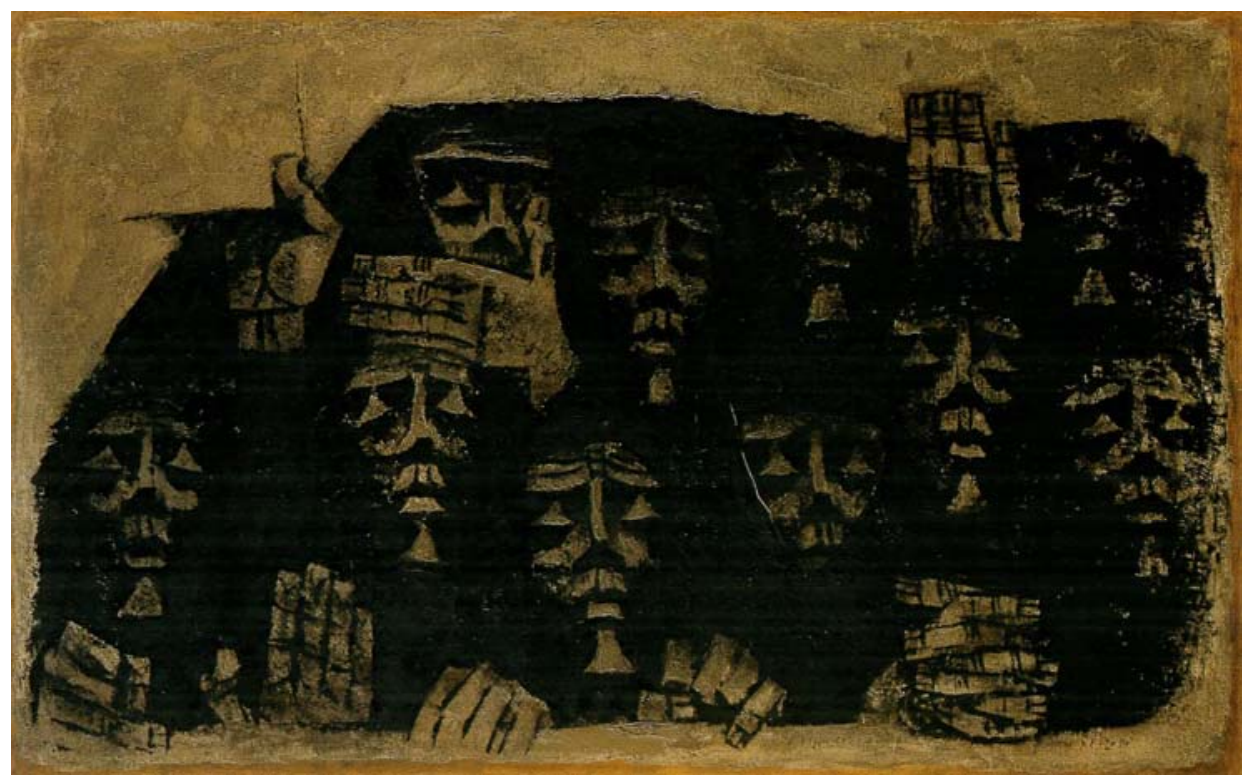

Puc. 7. Ясуо Кадзуки. Беглецы. Холст, масло, 1959

Fig. 7. Yasuo Kazuki. Jail-breakers. Painting in oil, 1959

Если японские пленники в лагере не обладали в полной мере своими телами, не имея права распоряжаться собой и принимать решения, то советские заключенные в застойные 70-е гг. в такой мере голод не испытывали, на тяжелых работах «не вкалывали». Но и те, и другие находились в тотальном институте, по выражению Эрвина Гоффмана, - в лагере, который был призван бороться с индивидуальностью заключенного, в котором все носили одинаковую одежду и прическу, жили по одному расписанию и имели номера вместо имен. Японские пленники только в последние, более благополучные годы плена могли думать о сексуальной жизни, да и то не все, в то время как солагерники Параджанова изнывали от своей сексуальности, умоляя его рисовать женские образы и порносюжеты для эротических практик.

В лагерях ГУПВИ медицинский осмотр пленников заключался преимущественно в проверке подкожного жира на ягодице у истощенных людей. Это самый распространенный сюжет всего лагерного изобразительного метатекста бывших узников из Японии [Гучинова, 2016, с. 170]. Это еще одна иллюстрация «политической анатомии», которую Мишель Фуко связывал с «механикой власти», производящей подчиненные, «послушные» тела [Фуко, 1999, с. 201]. В самом явном виде это проявилось в XX в., когда тоталитарные режимы использовали миллионы людей в своих лагерях, принуждая их работать с необходимой эффективностью.

Если наиболее распространенным заболеванием в лагерях сталинской эпохи была дистрофия, то в лагерных образах Сергея Параджанова мы видим как наиболее злободневную проблему медосмотра сифилис [Калейдоскоп Параджанова..., 2008, с. 80]. Другие времена, другие лагеря, другие нравы, и когда 58-ю ста- 
тью, политических, все-таки отпустили, в советской зоне остались преимущественно воры, со всеми традициями воровского мира, описанными Варламом Шаламовым.

\section{Портреты зеков и деперсонализация военнопленных}

Сохранение субъектности у советских зеков, не знавших проблемы выживания как коллективной проблемы, отразилось в многообразии тюремных типажей. Параджанов создал целую галерею солагерников в серии «Кент», и все они поражают колоритностью и разнообразием образов (рис. 8 ).

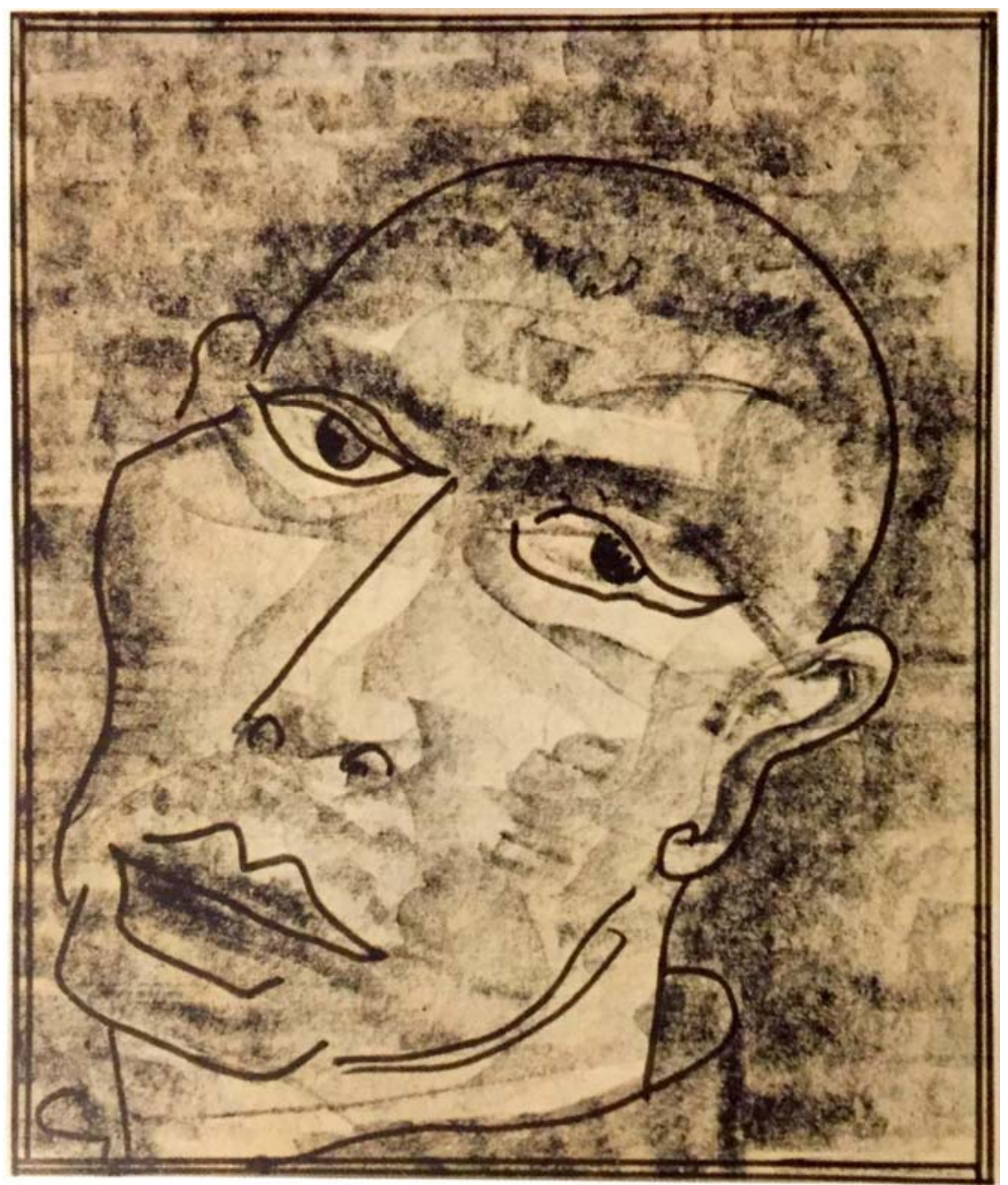

Рuc. 8. Сергей Параджанов. Из серии «Кент». Рисунок на бумаге, 1974-1977 Fig. 8. Sergei Parajanov. From the series «Kent» [«Buddies»]. Drawing on paper, 1974-1977 
В то же время все солагерники Кадзуки, которых мы видели выше, а также на многих других картинах, например на картине «На север, на запад», имеют одно и то же лицо. Как писал сам автор,

лица, нарисованные мной, это одни и те же лица. Я это делал, специально отказываясь от личности. Пока солдат остается солдатом, у него нет личности. Я рисую солдат с одним лицом. То, что я хочу рисовать, - это не индивидуальный солдат, а солдат как таковой [Kazuki, 1994, с. 158].

Кадзуки употребляет слово «солдат» вместо слова «военнопленный» или «заключенный». Это терминологическая игра нежелания называть солдат, выполнивших приказ высшего командования, пленными, поскольку они не сдавались в плен по собственной воле.

Кадзуки Ясуо показывает пленников в товарном вагоне, у которых лица неотличимы. Их везут, как щебень, как камни, как строительный материал (рис. 9). В этой его работе в камнях, перевязанных в ящике, узнаем героев рис. 7 - пленников, лица которых также неотличимы друг от друга, как и камни. Как и у камней, у пленников нет свободы выбора и воли, они, как и камни, - строительный материал для чужого блага, чужого будущего. Здесь уместно вспомнить рассуждения Вардана Айрапетяна о дзенском саде камней во дворе монастыря Реандзи. Пятнадцатый камень невозможно увидеть. Взгляд наблюдателя всегда охватывает на один камень меньше ${ }^{1}$. Именно так не могут сосчитать себя работники в анекдоте про девятых людей, недосчитываясь каждый раз одного: ведь человек не видит себя со стороны, не может себя сосчитать [Айрапетян, 2010].

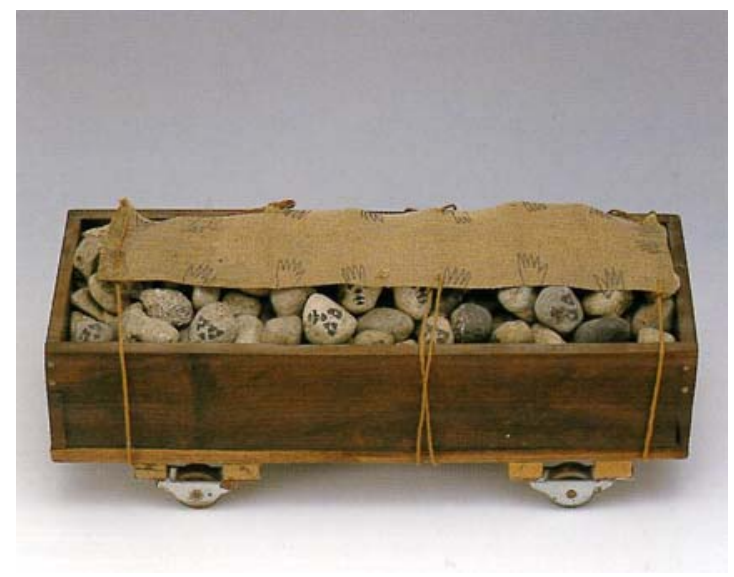

Puc. 9. Ясуо Кадзуки. Беглецы. Объект, 1959

Fig. 9. Yasuo Kazuki. Jail-breakers. Object, 1959

Лагерь живет законами больших чисел: типовая ситуация лагеря - это общие работы, быстро превращающие заключенного в доходягу и лишающие индивидуального опыта вместе с «индивидуализацией», «характером» и цветом глаз, кото-

\footnotetext{
${ }^{1}$ Устное сообщение Вардана Айрапетяна, август 2012 г.
} 
рого, по словам Шаламова, у заключенных на Колыме нет. Сведе́ние ценности человека и человеческого к нулю - вот неотъемлемая черта социума, заданного как принудительно мобилизованная масса [Агамбен, 2008, с. 59].

\section{Куклы и люди}

Пленные японцы в 40-е гг., советские люди в 70-е были винтиками системы и не могли ей противостоять, они были куклами для нее, включая даже такую сложную фигуру в советской культуре, как Лиля Брик, которой Параджанов посвятил свою первую куклу, изготовленную в лагере из мешковины. Ассамбляж «Вор никогда не станет прачкой» ${ }^{2}$ апеллирует к подлинной истории. Как-то Параджанов подметал лагерный двор, и проходивший мимо начальник сделал замечание, что он, дескать, работает без огонька. Параджанов поджег метлу, «чтобы доказать, что умеет работать с огоньком» [Калейдоскоп Параджанова..., 2008, c. 81]. Здесь «кукла изображает самого Параджанова. Название композиции воровская пословица. Подобно тому как вор всегда останется вором, «никогда не станет прачкой», настоящий художник всегда останется художником, не потеряет внутренней свободы» [Там же].

В этой композиции, как заметил антрополог Левон Абрамян, главное - цепь, на которой висит герой [Абрамян, 2008, с. 23]. Цепь, отсылающая наши ассоциации к прикованным героям или к рабам, также напоминает цепных животных и брелоки. А в черной руке кукловода мы узнаем мандельштамовские «руки брадобрея», такие же отвратительные, как и власть, играющая судьбами людей, интересно, что «цирюль» из другой работы Параджанова имеет сходное с черной рукой кукловода очертание (рис. 10). Появляются куклы и в работах Кадзуки, который создавал крохотных лесорубов (рис. 11). Они неслучайно напоминают игрушки, отражая историю военнопленных, ставших игрушками в руках злой судьбы.

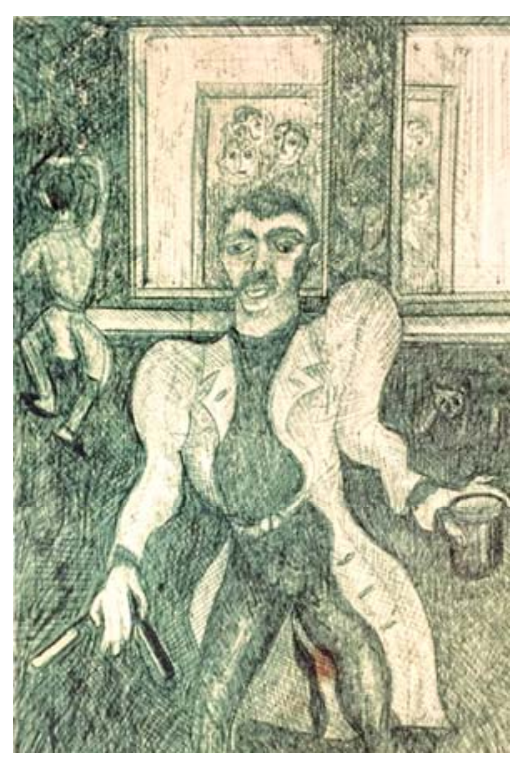

Рис. 10. Сергей Параджанов. Цирюль и цирюльня. Из серии «Сифилис в зоне». Рисунок на бумаге, 1974-1977

Fig. 10. Sergei Parajanov. Barber and barbershop.

From the series «Syphilis in Prison». Drawing on paper, 1974-1977

\footnotetext{
${ }^{2}$ См. рис. 7 в статье А. Микаелян в настоящем издании.
} 


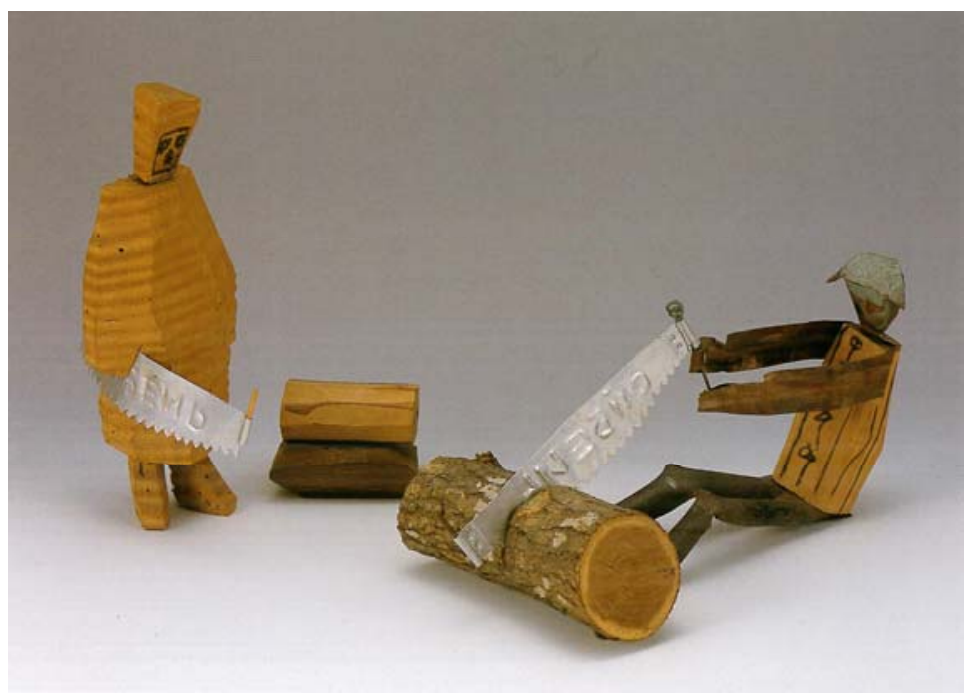

Puc. 11. Ясуо Кадзуки. Лесорубы. Объект, год не известен Fig. 11. Yasuo Kazuki. Wood-cutters. Object, date unknown

Гроб или ящик с останками, исполненный Кадзуки в 1959 г. (рис. 12), перекликается с отношением к работе памяти как к раскопкам, как будто задает тон в вопросе о лагерных годах - легко похоронить тяжелое прошлое в памяти не удастся.

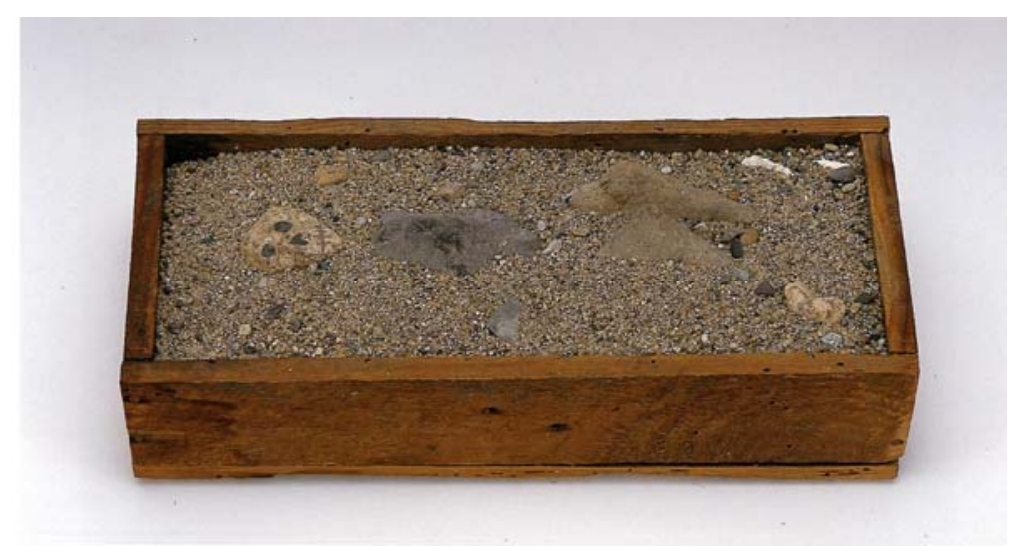

Puc. 12. Ясуо Кадзуки. Объект. 1959

Fig. 12. Yasuo Kazuki. Object. 1959

После перестройки в Сибири стали регулярными приезды японских делегаций в поисках заброшенных лагерных кладбищ, чтобы забрать прах японских военнопленных на родину и воздать им должные почести. Эти приезды порой называют в Сибири «могильными» турами, и здесь особенно уместны строки Анны Ах- 
матовой о русской земле, в которую «мы ложимся и становимся ею, потому и зовем так свободно - своею». В данном случае мы видим, как не становятся японцы русской землей, как и после смерти они остаются японцами. Может быть, потому и гроб, что перед нами, портативного размера, удобный для транспортировки на родину?

\section{Портреты и автопортреты}

На рисунке Кадзуки «Прощание» (рис. 13) изображено лицо человека, на лице видны муки: человеку дискомфортно. Лицо не прорисовано, оно набросано вчерне, как будто это только черновик человека или глыба, из которой только начинается человек, у которой еще не убрали все лишнее, или, наоборот, глыба, в которую превращается человек. Но вот в районе шеи - важном органе, связанном с дыханием, - синонимом жизни - автор считает важным изобразить два главных символа советской власти - пятиконечную звезду и красное знамя. Как будто эти два символа застревают в горле человека, не дают свободно дышать и, значит, свободно жить, но и просто проглотить их тоже нельзя.

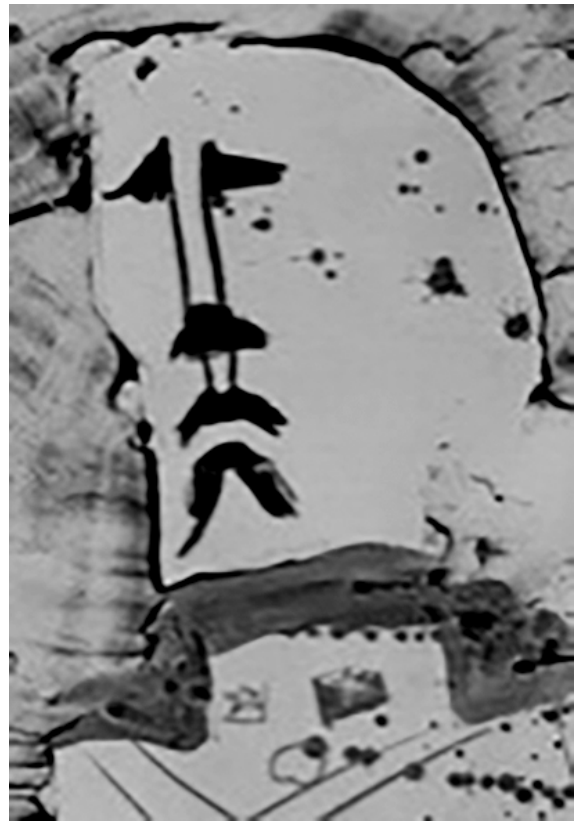

Puc. 13. Ясуо Кадзуки. Прощание. Холст, масло, 1967

Fig. 13. Yasuo Kazuki. Farewell. Canvas, oil, 1967

В ассамбляже «Пленник» (рис. 14), представляющем портрет заключенного, Ясуо Кадзуки определяет пленника как человека, сидящего за решеткой и думающего только о табаке и еде, свидетельством чего являются пустая ложка и трубка без табака. Если мы вспомним о крышках из фольги от кефирных и молочных бутылок, ставших у Параджанова талерами, то эта решетка напоминает проволоку от бутылки шампанского. 


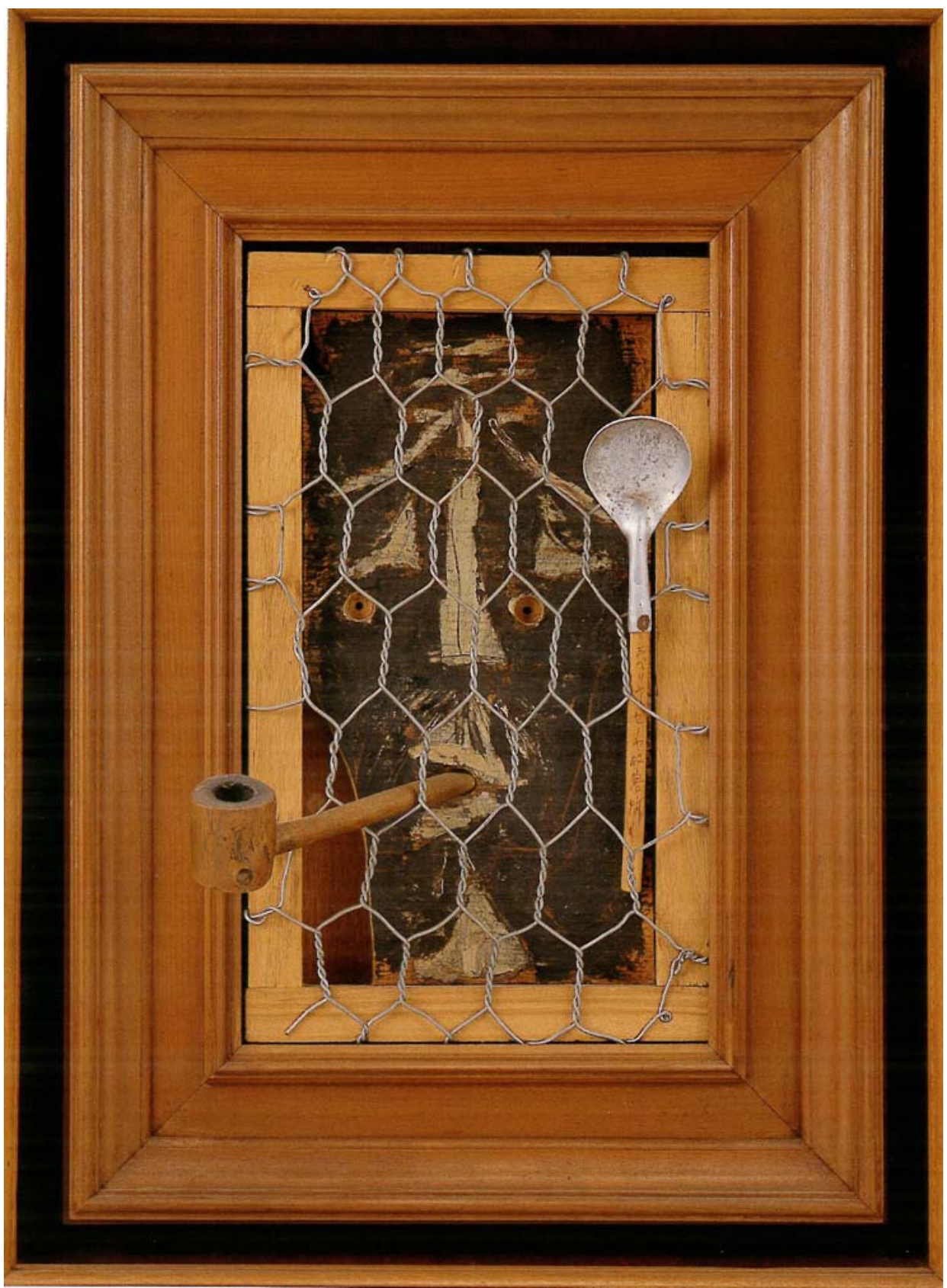

Puc. 14. Ясуо Кадзуки. Пленник (Автопортрет с трубкой). Ассамбляж, год не известен

Fig. 14. Yasuo Kazuki. The Captive (Self-portrait with pipe). Assemblage, date unknown 
Кадзуки работает над портретом пленника, минимизируя лицо. Например, на картине «Лицо пленника в зимнем окне» на лице у пленника пропадает плоть и только кости образуют - нет, не скелет, а какой-то новый инструмент то ли для плотницких работ, то ли для работы каменщика.

В итоге Кадзуки создает свое лого (рис. 15) - это такое лицо пленника, которое становится рабочим инструментом, в котором мы смутно угадываем лицо человека, тот костяк, в который превращается лицо доходяги, но еще не «мусульманина», как называли в нацистских концлагерях доходяг на последней стадии еле теплившейся жизни. У этого доходяги еще сохранилась воля к жизни. Автор решил, что лучше всего именно этот образ отражает существо самого Кадзуки, видимо, потому что пленник долго жил в душе художника, а художник, живший в душе пленника, помог ему выжить.

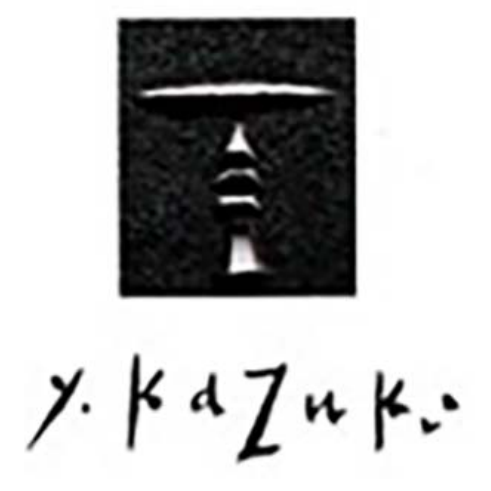

Рuc. 15. Лого Ясуо Кадзуки. Год не известен

Fig. 15. Logo of Yasuo Kazuki. date unknown

Теперь рассмотрим портреты и автопортреты Сергея Параджанова. Образ мученика, творившего вопреки воле властей, складывался еще до ареста, - с арестом он канонизируется [Сергей Параджанов..., 2000, с. 8]. Такова фотография Параджанова, сделанная на Украине в 1960-х гг. и скорее всего срежиссированная им самим (рис. 16). Но мы видим терновый венец, избыточно сложенный втрое - как жемчужное ожерелье Джекки Кенеди. И то, что Ролан Барт назвал «пунктум» деталь на фотографии, которая цепляет глаз, - это пустые глазницы. Еще относительно молодой Параджанов уже чувствует свою судьбу, уже знает, «что случится на его веку».

Перед нами фотография Сергея Параджанова, сделанная в 1980 г. (рис. 17). Он уже вышел из лагеря. Не только седина говорит о перенесенных тяготах, сам Параджанов рисует знаки лагеря - колючую проволоку, легко перечеркивающую личность человека, нимб - терновый венец из колючей лагерной проволоки и ножницы, разрезающие эти путы, мешавшие художнику жить и творить.

В конце концов Параджанов создает свое лого (рис. 18) - автопортрет, отражая главные знаки судьбы, - лицо художника, перечеркнутое лагерной проволокой, 


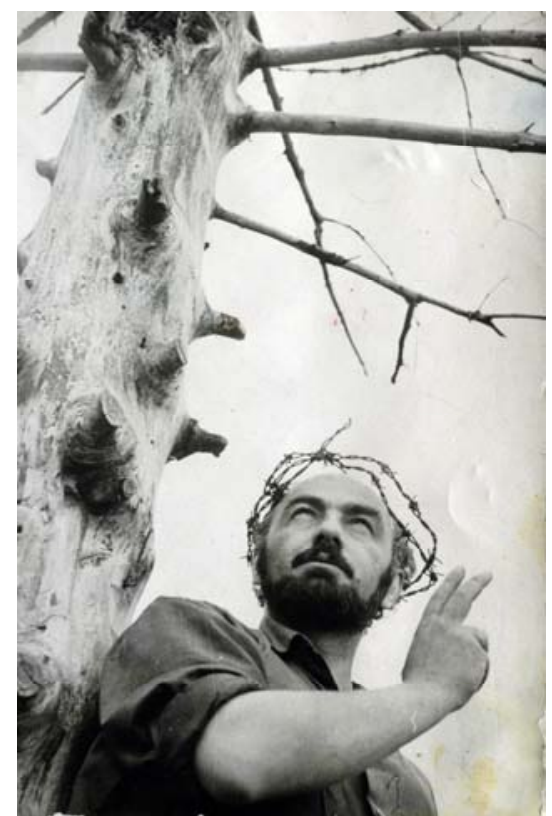

Puc. 16. Сергей Параджанов. Фотография 1960-х гг. Fig. 16. Sergei Parajanov. Photography of 1960 s

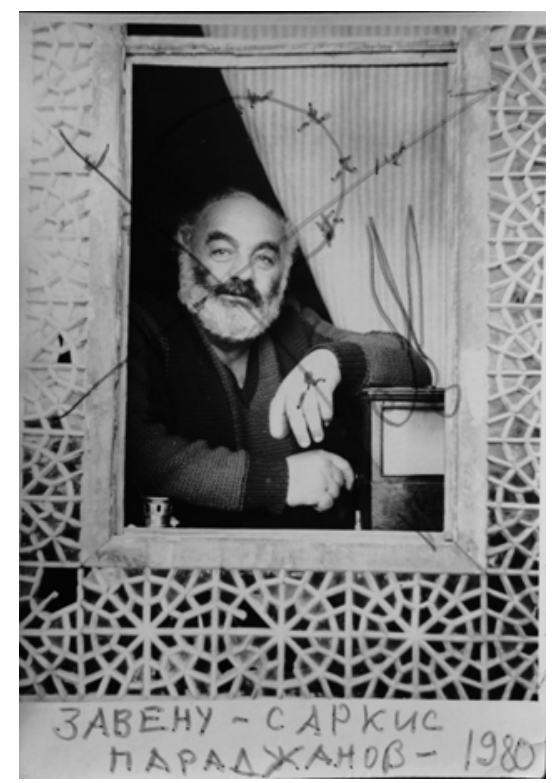

Puc. 17. Сергей Параджанов в своем тбилисском доме. Фото 3. Саргсяна с автографом Параджанова. 1980

Fig. 17. Sergei Parajanov in his Tbilisi house.

Photo by Z, Sargsyan with Parajanov's autograph, 1980 


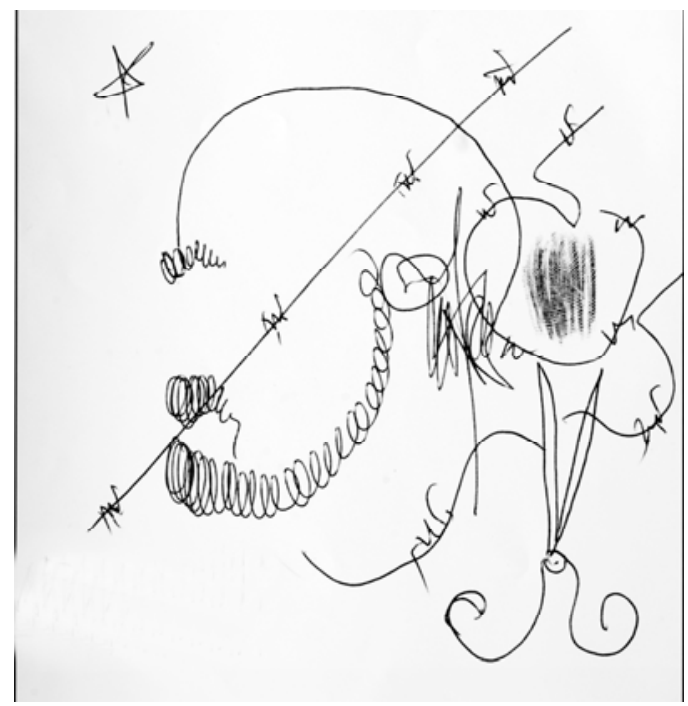

Puc. 18. Лого Параджанова. 1977

Fig. 18. Logo of Parajanov. 1977

первая буква имени в форме граната, ножницы, готовые перерезать проволоку. В центре композиции - оттиск большого пальца внутри буквы C, дактилоскопическая подпись арестанта и его уникальная идентичность. Драматичность композиции придает и знак времени - маленькая пятиконечная звезда в левом углу. Дает ли она свет, не видно, но очень напоминает такие же звездочки на колючей проволоке в работах Ясуо Кадзуки.

\section{Список литературы}

Абрамян Л. Кинорежиссер, смотрящий на мир глазами художника // Калейдоскоп Параджанова. Рисунок, коллаж, ассамбляж / Сост. 3. Саркисян, коммент. 3. Саркисян, Л. Абрамян; Музей Сергея Параджанова. Ереван, 2008. С. 19-29.

Агамбен Дж. Что остается от Аушвица. Архив и свидетельство // Отечественные записки. 2008. № 4. С. 58-59.

Айрапетян B. Толкование на анекдот про девятых людей (АТ 1287). М.: Языки славянской культуры, 2010. 71 с.

Гучинова Э.-Б. Рисовать лагерь. Язык травмы в памяти японских военнопленных о CCCP. Sapporo: Slavic-Eurasian Research Center, Hokkaido University, 2016. $220 \mathrm{c}$.

Калейдоскоп Параджанова. Рисунок, коллаж, ассамбляж / Сост. 3. Саркисян, коммент. 3. Саркисян, Л. Абрамян; Музей Сергея Параджанова. Ереван, 2008. $155 \mathrm{c}$.

Катасонова Е. Японские военнопленные в СССР: большая игра великих держав. М.: Ин-т востоковедения РАН; Крафт+, 2003. 427 с.

Кузнецев С. И. Японцы в сибирском плену (1945-1956). Иркутск: Изд-во журнала «Сибирь», 1997, 261 с. 
Мешеряков А. Н. Стать японцем. М.: Эксмо, 2012. 432 с.

Нич Д. Московский рассказ. Жизнеописание Варлама Шаламова. 1960-1980-е годы. Личное издание. 2011. 448 с.

Орозбаев K. Планета Сергея Параджанова // Виноград. 2011. № 2 (40). URL: http://www.vinograd.su/art/detail.php?id=44035 (дата обращения 20.05.2019).

Сергей Параджанов: Письма из зоны / Автор проекта и гл. ред. Г. Закоян. Ереван: Фильмадаран, 2000. 347 с.

Фуко M. Надзирать и наказывать. Рождение тюрьмы / Пер. с фр. В. Наумова. M.: Ad Marginem, 1999. 477 c.

Шаламов В. Манифест о «новой прозе» // Вопросы литературы. 1989. № 5. C. $225-248$.

Kazuki Yasuo. Watashi-no Siberia. Misumi, 1994. 123 p.

\section{Article metadata}

Title: Black Sun and Ring-Fenced Space: Images of Captivity in the Art of Sergey Parajanov and Kazuki Yasuo

Author: E.-B. M. Guchinova

Author's e-mail: kigiran@mail.ru

Author's affiliation: Kalmyk Scientific Center RAS

Abstract. The article is devoted to the art of two outstanding artists - Sergey Paradzhanov (USSR) and Kazuki Yasuo (Japan). Sregey Paradjanov was convicted and spent five years in camps, Yasuo Kazuki found himself in a Soviet camp for prisoners of war. The humiliating experience of the imprisonment of artists was reflected in their works, which did not cease behind barbed wire. But both artists are united by the theme of human freedom in unfree conditions, where the boundaries of freedom can be outlined by the boundaries of a totalitarian state, and by military order at the front, and by barbed wire of a camp fence.Paradzhanov and his camp creativity and outlined - fenced open space. He and Kazuki used bricolage techniques, and the Japanese artist himself composed the composition of colors, since the factory colors do not convey the alien black sun. At the same time, their presence in fundamentally different camps (camps and GUPVI camps) was reflected in the portraits of the prisoners: Parajanov's campers had no need to survive, and Parajanov painted their colorful faces, tired of hunger and excessive labor, Japanese prisoners of war depersonalized and Kazuki painted them with the same faces. By the way, bodily practices were different: Paradzhanov's fellow campers suffered from syphilis, and Kazuk's fellow campers suffered from dystrophy. Paradzhanov and Kazuki create dolls that, by their own genre, reflect the depersonalization process and the puppet dependence of man in the hands of a totalitarian state. However, the fact that after the camp they became different, that the camp experience remained with the artists forever reflected in their self-portraits and especially in the logo. Sergey Paradzhanov in his logo depicted not only his profile, but also a thumbprint inside the letter C., this shows the prisoner's fingerprint and his unique identity, as well as the barbed wire. Kazuki in his logo shows a self-portrait in which he removed all the details and instead of a human face the captive's working tool appears.

Key terms: trauma language, traumatic past, camp, Gulag, memory. 
Reference literature (in transliteration):

Abramyan L. Kinorezhisser, smotryashchii na mir glazami khudozhnika. In: Kaleidoskop Paradjanova. Risunok, kollazh, assamblyazh [The Parajanov Kaleidoscope. Drawings, Collages, Assemblages]. Comp. by Z. Sargsyan, comment. by Z. Sargsyan and L. Abrahamian. Yerevan, Sergey Parajanov Museum, 2008, p. 19-29. (in Russ.)

Agamnen J. Chto ostaetsya ot Aushvitsa. Arkhiv i svidetel'stvo [What stays of Auschwitz. Archive and evidence]. Otechestvennye zapiski [Domestic Proceedings], 2008, no. 4, p. 58-59. (in Russ.)

Ayrapetyan V. Tolkovanie na anekdot pro devyatykh lyudei (AT 1287) [Interpretation of the anecdote on the nine people (AT 1287)]. Moscow, Yazyki slavyanskoi kul'tury [Languages of Slavonic Culture], 2010, 71 p. (in Russ.)

Guchinova E.-B. Risovat' lager'. Yazyk travmy v pamyati yaponskikh voennoplennykh o SSSR [To draw a prison. The language of trauma in the memories about USSR of the Japanese war prisoners]. Sapporo, Slavic-Eurasian Research Center, Hokkaido University, 2016, 220 p. (in Russ.)

Kaleidoskop Paradjanova. Risunok, kollazh, assamblyazh [The Parajanov Kaleidoscope. Drawings, Collages, Assemblages]. Comp. by Z. Sargsyan, comment. by Z. Sargsyan and L. Abrahamian. Yerevan, Sergey Parajanov Museum, 2008, 155 p. (in Russ.)

Katasonova E. Yaponskie voennoplennye v SSSR: bol'shaya igra velikikh derzhav [Japanese war prisoners in the USSR: a great game of the Great Powers]. Moscow, Institute of Oriental Studies of RASci; Kraft+, 2003, 427 p. (in Russ.)

Kuznetsov S. I. Yapontsy v sibirskom plenu (1945-1956) [The Japanese in the Sibirian captivity (1945-1956)]. Irkutsk, Publishing House of «Siberia» Journal, 1997, 261 p. (in Russ.)

Meshcheryakov A. N. Stat' yapontsem [To become a Japanese]. Moscow, Eksmo, 2012, 432 p. (in Russ.)

Nich D. Moskovskiy rasskaz. Zhizneopisanie Warlama Shalamova. 1960s - 1980s [A Moscow story. Biography of Varlam Shalamov. 1960s - 1980s]. A Private Edition, 2011, 448 p. (in Russ.)

Orozbaev K. Planeta Sergeya Parajanova [Sergei Parajanov's planet]. Vinograd, 2011, no. 2 (40). URL: http://www.vinograd.su/art/detail.php?id=44035 (20.05.2019). (in Russ.)

Sergei Parajanov: Pis'ma iz zony [Sergei Parajanov: Letters from prison]. Author of the project and ed. in chief G. Zakoyan. Yerevan, Filmadaran, 2000, 347 p. (in Russ.)

Foucault M. Nadzirat' i nakazyvat'. Rozhdenie tyur'my [To supervise and to punish. The birth of the prison]. Transl. from French by V. Naumov. Moscow, Ad Marginem, 1999, 477 p. (in Russ.)

Shalamov V. Manifest o «novoi proze» [A manifest on the "new prose"]. Voprosy literatury [Literature issues], 1989, no. 5, p. 225-248. (in Russ.)

Kazuki Yasuo. Watashi-no Siberia. Misumi, 1994, 123 p.

DOI 10.25205/2307-1737-2019-2-78-99 